\title{
FREE DIETS IN THE TREATMENT OF DIABETIC CHILDREN
}

\author{
BY \\ CONSTANCE C. FORSYTH and W. W. PAYNE \\ From The Hospital for Sick Children, Great Ormond Street, London
}

(RECEIVED FOR PUBLICATION APRIL 9, 1956)

There is no doubt that the severity of diabetes mellitus can be modified by a restriction of the total calorie intake. This fact, established experimentally by Allen $(1914,1917)$, was the bulwark of treatment before the discovery of insulin, and low-calorie diets are still today the best method of treatment for obese diabetics. After the introduction of insulin, children survived long enough to show that the undernutrition inherent in this method resulted in stunting of growth and, in many cases, enlargement of the liver. In view of this and the rarity of obesity in diabetic children, diets were progressively increased until at the present time it is generally accepted that they should be of normal calorie value (White, 1952). Children's activities are variable, their emotions labile and their appetites capricious. It is not surprising, therefore, that the next step towards normality, namely the use of free diets, was first reported from a children's clinic by Stolte (1931). Other paediatricians, including Lichtenstein (1938, 1945, 1949), Larsson, Lichtenstein and Ploman (1952) and Guest (1947, 1950), have since written in favour of this method.

The clinic for diabetic children at The Hospital for Sick Children, Great Ormond Street, was started in 1926. Initially, strictly weighed diets were used with a carbohydrate content of up to 100 grams daily. However, it soon became apparent that many of the children were hungry and that they were not growing well. The food intakes were gradually increased until normal in quantity and in 1936 free diets were tried for the first time. A few years later it was reported (Payne, 1939) that none of the children was more difficult to control on a free diet, and that in some control was actually easier. About this time the free diet method was adopted for the whole clinic and the availability of delayed-action insulins made control possible with one injection daily. The question arose, however, would these children in the long run show a higher incidence of complications than their contemporaries treated on strict diets? The following study of the long-term results on the method was undertaken to try to provide the answer.

It is impossible to include every diabetic treated since 1926, because at least a third of the patients were lost sight of during the war years. The paper deals only with those regularly attending and those who came for examination in response to our letter and were still on a free diet. One hundred patients were seen (a fortuitous total), 54 male and 46 female. In 41 cases the duration of diabetes exceeded 15 years and the others had been diabetic for between one and 15 years. Their ages ranged from 3 to 41 years and the longest period on a free diet was 18 years. The patients were interviewed and examined, particularly for evidence of retinal degeneration, and neurological, renal or vascular disturbances. Each had a chest radiograph, the blood sugar and cholesterol estimated and the urine examined for sugar, acetone, albumin, cells and casts. Mr. J. H. Doggart also examined the retinae in many cases and his opinion confirmed ours. For the few patients who could not visit his clinic this specialist corroboration was, however, not obtainable.

By the term 'free diet' we imply liberty rather than licence. Simple instructions are given to ensure the quality of the diet, and regular timing of meals is considered essential. Concentrated carbohydrates, such as table sugar, jam, chocolate and sweets, are restricted. It might conveniently be described as a Victorian diet providing unlimited quantities of plain fare. In practice, because the importance of avoiding insulin reactions is soon appreciated, cooperation is excellent with regard to the regularity of meals, and when the diets are analysed they are remarkably similar from day to day. It might be argued that the diet employed is not truly free; we agree. However, there is a real difference between such a simple diet and a strictly weighed diet demanding much care and intelligence from the parent and strict obedience from the child.

With regard to the standard of control to be set 
in the early years of the clinic a stalwart attempt was made by using strict diets to keep the blood sugars normal and the urine sugar-free. In most children, however, this ideal was unattainable, so instead a more realistic target was adopted, namely, no symptoms either of thirst or polyuria or of insulin overdosage, normal growth and weight gain, no ketonuria, about half the urine tests done at home at varying times of day before meals to be sugar-free or virtually so, and the blood sugar level taken at the monthly visit to the clinic to be below $250 \mathrm{mg}$. \%. The group of diabetics studied was divided into three categories according to the control actually achieved. Group A maintained the above standards of control for over three-quarters of their diabetic life, group B for between half and threequarters of the time and group $C$ for less than half of the time. Twenty-nine were in category $A$, 40 in category $B$ and 31 in category $C$.
Following the introduction of delayed-action insulins, control by a single morning dose in suitable combination has been achieved in every patient. In the group of diabetics who have been under observation for more than 15 years, the dose of insulin steadily increased during childhood, reached its maximum at puberty and then fell to a fairly stable adult level. This typical pattern is illustrated for six of the boys and six girls in Figs. 1 and 2 . Some showed a more even distribution of insulin over the years, but in only two did the final adult level exceed that at puberty. In the whole group the range of insulin requirement at 12 years was from 20 to 70 units, during puberty from 60 to 180 units and in adult life from 40 to 120 units. The steep rise in insulin dosage in adolescents was noted in a previous study of the use of 'free' diets (Forsyth, Kinnear and Dunlop, 1951), and most of the young people were changed on to restricted

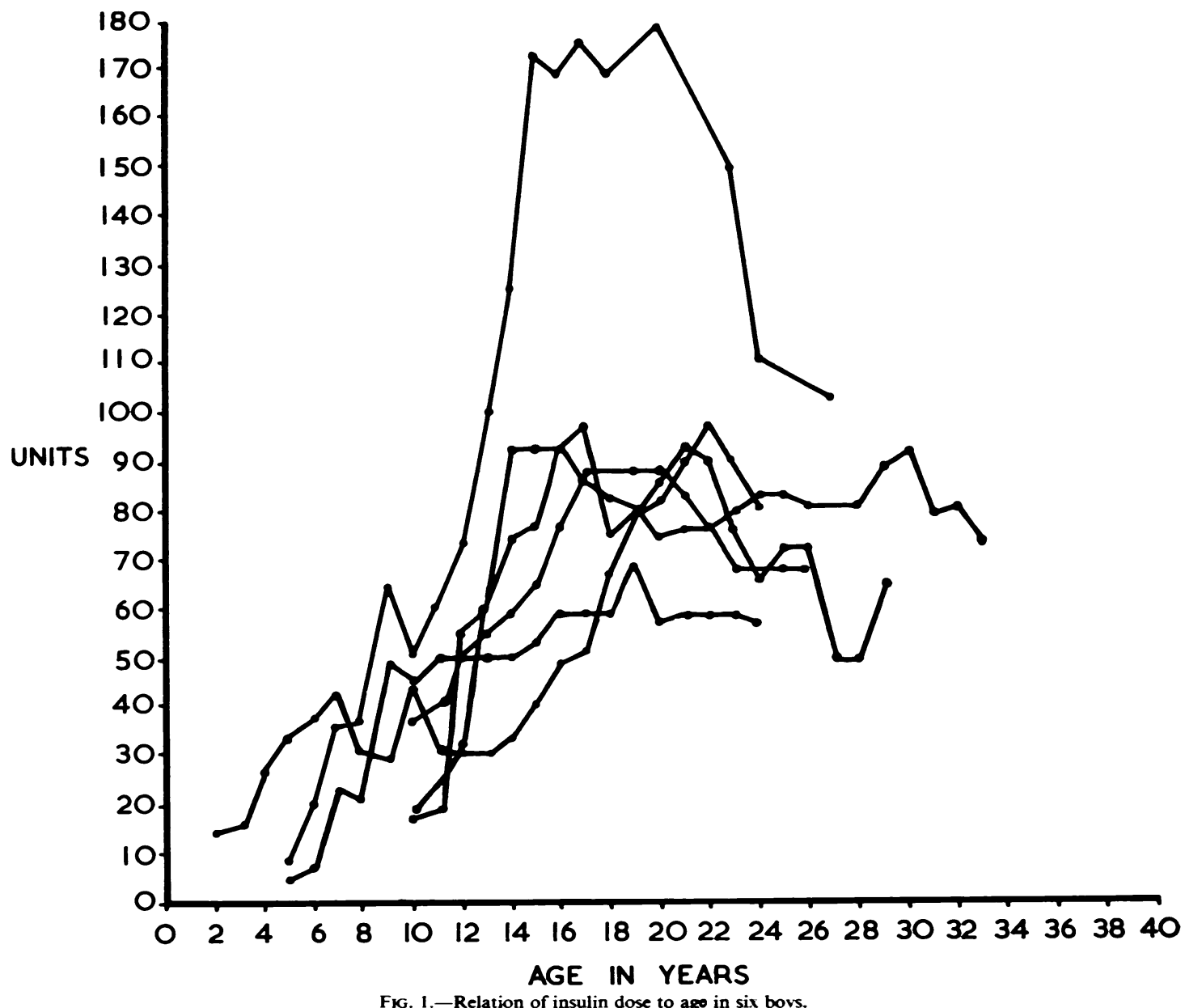

Fig. 1.-Relation of insulin dose to ago in six boys. 
diets as levels of insulin requirement above 80 units were then regarded as excessive. In the present group, over half the patients required more than 80 units for a few years at puberty but only one-fifth take more than 80 units as adults. The increase is not, as was supposed, due to a progressive impairment of carbohydrate tolerance, but is a phase in the natural history of the disease.

Reviewing the results of treatment of the hundred children on a free diet, we have found, except for short periods of loss of balance due usually to intercurrent infections, that all have remained entirely free from thirst, polyuria or ketosis. Insulin reactions have been mild and hypoglycaemic coma has been very rare. Detailed figures for the incidence of diabetic coma are not available for the group diabetic for more than $\mathbf{1 5}$ years, as they have not been under supervision at Great Ormond Street all the time. Of the 59 younger patients, five have had one coma, and only one child two episodes of coma, apart from those at the onset of diabetes. It must be admitted that timely advice on the telephone averted trouble on many occasions, and several children were saved from coma by prompt hospital treatment during acute infections accompanied by ketosis. The heights of those patients now over 20 years are given in Table 1 and

TABLE 1

HEIGHTS OF ADULT PATIENTS

\begin{tabular}{|c|c|c|c|c|}
\hline Sex & $\begin{array}{l}4 \mathrm{ft} .11 \mathrm{in} . \\
\text { to } 5 \mathrm{ft} .2 \mathrm{in} .\end{array}$ & $\begin{array}{l}5 \mathrm{ft} .3 \text { in. } \\
\text { to } 5 \mathrm{ft} .6 \text { in. }\end{array}$ & $\begin{array}{r}5 \mathrm{ft.} 7 \mathrm{in} . \\
\text { to } 5 \mathrm{ft} .10 \mathrm{in} .\end{array}$ & $\begin{array}{l}5 \mathrm{ft} .10 \mathrm{in} . \\
\text { to } 6 \mathrm{ft} .1 \mathrm{in} .\end{array}$ \\
\hline $\begin{array}{l}\text { Male (25) } \\
\text { Female (13) }\end{array}$ & $\begin{array}{l}0 \\
6\end{array}$ & $\begin{array}{l}4 \\
7\end{array}$ & $\begin{array}{r}18 \\
0\end{array}$ & $\begin{array}{l}3 \\
0\end{array}$ \\
\hline
\end{tabular}

it is evident that growth has been satisfactory. None of the adults has become obese but three girls

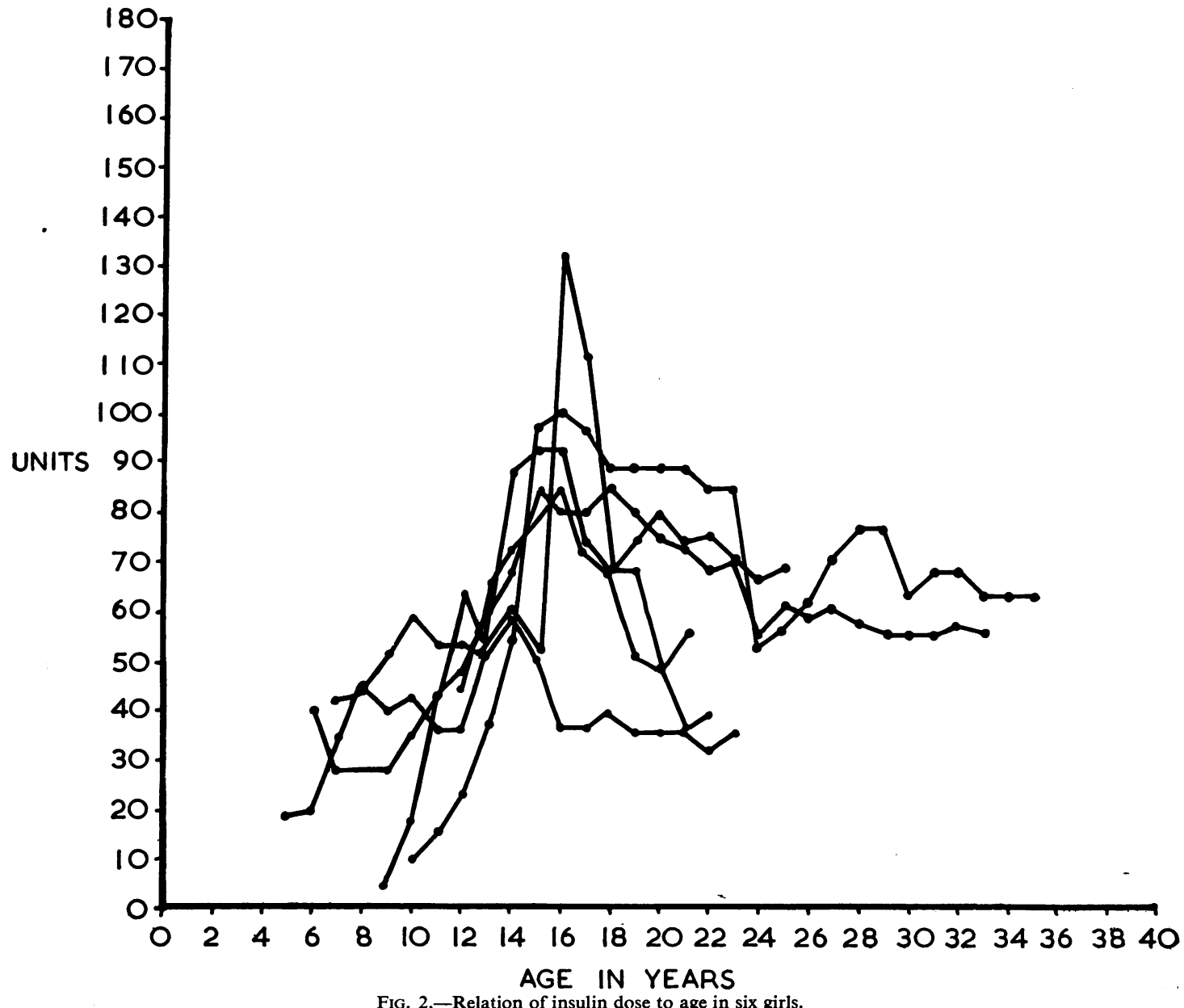

FIG. 2.-Relation of insulin dose to age in six girls. 
showed this tendency at puberty. A short period of restricted food intake corrected this, a treatment one would give to any normal girl showing too rapid a weight gain at this age.

Hepatomegaly used to be frequent in diabetic children treated on restricted diets but was uncommon in our series. In three children under 4 years of age, who were clinically and biochemically well controlled, the liver could be felt one fingerbreadth below the costal margin. In six children over 4 years of age, however, a similar finding was associated consistently with glycosuria. The liver was not palpable in any of the adults. Excluding the very youngest children, in whom a palpable liver may be quite normal for the age, this sign may be useful in assessing the efficiency of treatment.

The blood cholesterol levels were above $230 \mathrm{mg}$. \% in five out of 57 of the younger group, diabetic for less than 15 years. One of these had retinitis, one had xanthomatosis lipoidica diabeticorum, two were passing much sugar at the time, but a girl of 4 appeared to be well controlled. In the older group, 30 were tested, and of these three showed high blood cholesterol levels. All three were of control category $\mathrm{C}$ and are included in Table 5 which shows those with severe complications. The blood cholesterol levels appear therefore to be more labile in children, but are nevertheless a useful additional guide to overall control in difficult cases.

As part of the follow-up, the chest was radiographed. The radiographs were negative in all of the patients diabetic for less than 15 years. There have been four instances of tuberculosis among those diabetic for longer than 15 years and one of these had both pulmonary and renal tuberculosis. He is now convalescent and the other three are well again and back at work (Table 2). Five patients who had had diabetes for more than 15 years have died and are not included in the hundred cases. One of these developed pulmonary tuberculosis and died after a lobectomy (Table 3). In all cases, the onset of tuberculosis was between 15 and 24 years of age, the period of maximal incidence of the disease in the general population. Since 1950, B.C.G. immunization has been carried out as
TABLE 2

FOUR CASES OF TUBERCULOSIS

\begin{tabular}{|c|c|c|c|c|}
\hline Sex & $\begin{array}{c}\text { Age at } \\
\text { Onset } \\
\text { (years) }\end{array}$ & $\begin{array}{l}\text { Duration of } \\
\text { Illness } \\
\text { (years) }\end{array}$ & Outcome & $\begin{array}{c}\text { Control } \\
\text { before } \\
\text { Onset }\end{array}$ \\
\hline $\begin{array}{l}\mathbf{M} \\
\mathbf{M} \\
\mathbf{M} \\
\mathbf{F}\end{array}$ & $\begin{array}{l}24 \\
19 \\
23 \\
19\end{array}$ & $\begin{array}{l}3 \\
5 \\
6 \\
4\end{array}$ & $\begin{array}{l}\text { At work } \\
\text { At work } \\
\text { Convalescent } \\
\text { At work }\end{array}$ & $\begin{array}{l}\mathbf{C} \\
\mathbf{B} \\
\mathbf{A} \\
\mathbf{C}\end{array}$ \\
\hline
\end{tabular}

a routine in the clinic and this may have modified the incidence in the more recent patients.

None of the hundred patients complained of pains or paraesthesiae in the head, face, trunk or limbs, and neurological examination failed to reveal any instances of neuropathy. The vascular complications encountered were retinopathy, nephropathy and hypertension in that order of frequency. No cases of cerebral, coronary or peripheral vascular disease were detected clinically, but radiographs of the limb vessels were not taken. Of the five deaths in patients diabetic for more than 15 years, one was due to a cerebrovascular accident following pregnancy, one to renal failure following three pregnancies and one to renal failure in a single girl (Table 3).

Retinopathy was graded as follows: I, a few punctate haemorrhages only ; II, several haemorrhages and some exudates; III, visual impairment with marked haemorrhages and exudates and occasionally venous changes ; IV, certifiable as a blind person. The incidence and severity of retinitis in the hundred cases increased with the duration of the diabetes (Fig. 3). None of the blind patients had had diabetes for less than 20 years and two patients after 25 years of diabetes were free of retinitis. As there were no cases of retinitis in those diabetic for eight years or less, those 40 cases are omitted from Figs. 4 and 5. While it must be admitted that the daily insulin requirement does not reflect the clinical severity of diabetes, it was of interest to see if there was any correlation between retinitis and the dose of insulin (Fig. 4). No such relation emerged.

As at present the only factor which can be

TABLE 3

DEATHS IN THOSE SURVIVING 15 YEARS

\begin{tabular}{|c|c|c|c|c|c|c|c|}
\hline Sex & $\begin{array}{c}\text { Age at } \\
\text { Death (years) }\end{array}$ & $\begin{array}{c}\text { Duration } \\
\text { (years) }\end{array}$ & Control & Retinitis & Nephropathy & Hypertension & Cause of Death \\
\hline $\begin{array}{l}\mathbf{F} \\
\mathbf{F} \\
\mathbf{F} \\
\mathbf{F} \\
\mathbf{F}\end{array}$ & $\begin{array}{l}26 \\
25 \\
29 \\
19 \\
24\end{array}$ & $\begin{array}{l}23 \\
20 \\
20 \\
17 \\
20\end{array}$ & $\begin{array}{l}\text { B } \\
\text { C } \\
\text { C } \\
\stackrel{C}{C}\end{array}$ & $\begin{array}{r}\text { II } \\
\text { III } \\
\text { I }\end{array}$ & $\begin{array}{l}+ \\
+ \\
+ \\
+\end{array}$ & $\begin{array}{l}+ \\
+ \\
+ \\
-\end{array}$ & $\begin{array}{l}\text { Stroke: } 3 \text { pregnancies } \\
\text { Nephropathy } \\
\text { Nephropathy: } 1 \text { pregnancy } \\
\text { Pulmonary T.B. Lobectomy } \\
\text { Status asthmaticus }\end{array}$ \\
\hline
\end{tabular}




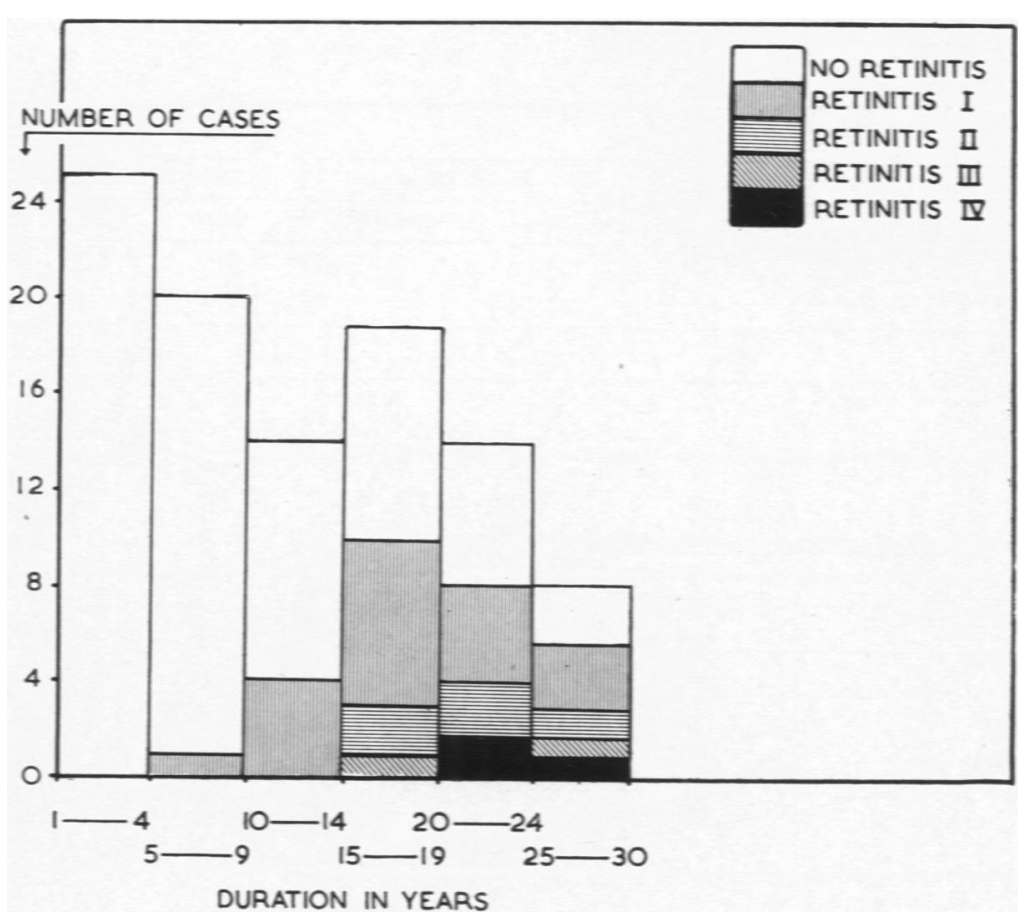

Fig. 3.- Relation of retinitis to duration of diabetes in 100 cases. made of such a series of figures as occur in Table 4B. Using this method the two series show a difference significant between the 0.05 and 0.01 level of probability. It will be seen then, that the incidence of retinitis is in each age group higher in category C. (It is of interest that the 25 year + group contains no cases in category C.) Thus only in those patients failing to satisfy the set standard of control for more than half of their period of diabetes was a rise in the incidence of retinitis noted. There was no difference between the two better controlled groups.

Nephropathy was diagnosed if there was a persistent albuminuria above $40 \mathrm{mg}$. \% whether casts were seen microscopically or not. Hypertension was considered present when the diastolic blood pressure was above influenced by the physician is the degree of control, $90 \mathrm{~mm}$. $\mathrm{Hg}$, taking the point when the character of the relation between the incidence of retinitis and degree of control is of importance. Examination of Fig. 5 reveals no difference in the incidence of the severer forms of retinitis in the three categories. There is, however, a suggestive increase in the total incidence of retinitis in group $C$. When the cases are arranged in relation to the duration of the disease, as well as their category (Table 4A), it will be seen that there is a very uneven distribution of cases of the different categories in the various age groups. By inspection it is evident that categories $\mathbf{A}$ and $\mathbf{B}$ show a similar incidence of retinitis. By adding groups $\mathbf{A}$ and $\mathbf{B}$ together it is possible to make a comparison with category C (4B). Armitage (1956) has devised a method enabling a statistical comparison to be

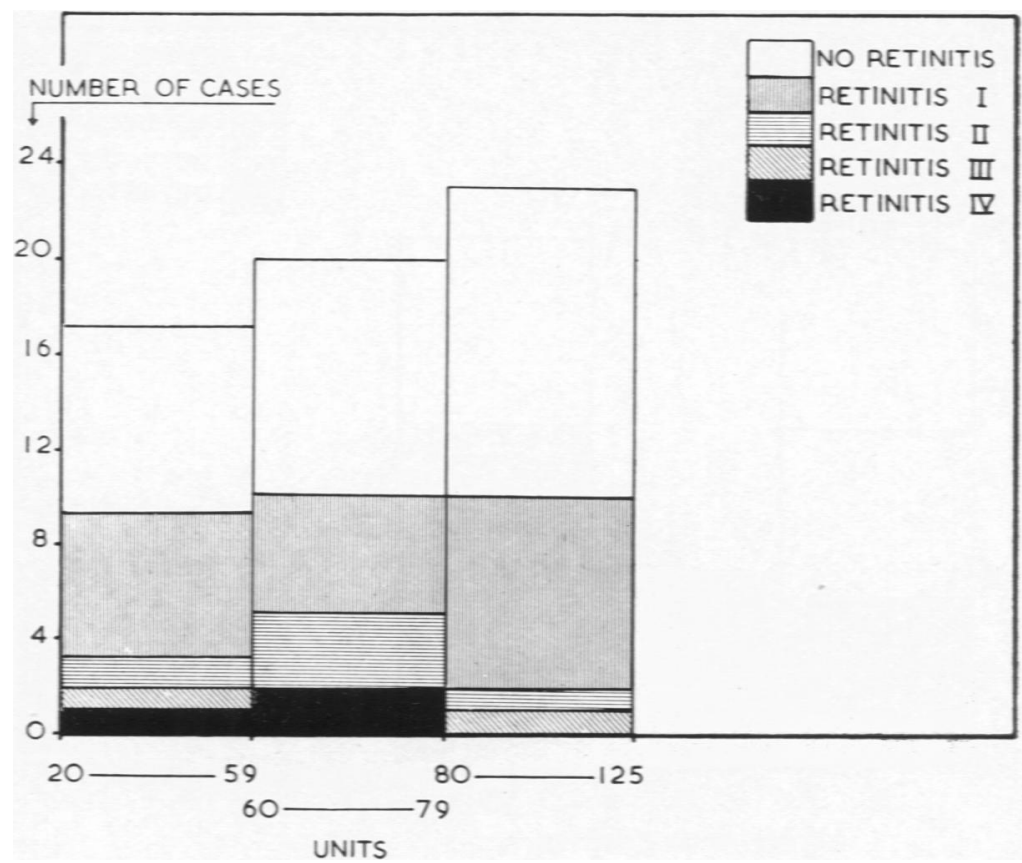

Frg. 4.-Relation of retinitis to insulin dose in 60 cases having had diabetes for nine years or more. 
TABLE 4A AND 4B

RETINITIS AND CONTROL

4A

\begin{tabular}{|c|c|c|c|c|c|c|c|c|}
\hline \multirow{3}{*}{ Category } & \multicolumn{8}{|c|}{ Duration } \\
\hline & \multicolumn{2}{|c|}{ 9-14 Years } & \multicolumn{2}{|c|}{ 15-19 Years } & \multicolumn{2}{|c|}{ 20-24 Years } & \multicolumn{2}{|c|}{ 25-30 Years } \\
\hline & Total & Retinitis & Total & Retinitis & Total & Retinitis & Total & Retinitis \\
\hline $\begin{array}{l}\mathbf{A} \\
\mathbf{B} \\
\mathbf{C}\end{array}$ & $\begin{array}{r}2 \\
10 \\
7\end{array}$ & $\begin{array}{l}0 \\
2 \\
3\end{array}$ & $\begin{array}{l}6 \\
5 \\
8\end{array}$ & $\begin{array}{l}3 \\
1 \\
6\end{array}$ & $\begin{array}{l}2 \\
5 \\
7\end{array}$ & $\begin{array}{l}1 \\
2 \\
5\end{array}$ & $\begin{array}{l}4 \\
4 \\
0\end{array}$ & $\begin{array}{l}3 \\
\mathbf{3} \\
0\end{array}$ \\
\hline \multicolumn{9}{|c|}{$4 B$} \\
\hline$\underset{\mathbf{C}}{\mathbf{A}+\mathbf{B}}$ & $\begin{array}{r}12 \\
7\end{array}$ & $\begin{array}{l}2 \\
3\end{array}$ & $\begin{array}{r}11 \\
8\end{array}$ & $\begin{array}{l}4 \\
6\end{array}$ & $\begin{array}{l}7 \\
7\end{array}$ & $\begin{array}{l}3 \\
5\end{array}$ & $\begin{array}{l}8 \\
0\end{array}$ & $\begin{array}{l}6 \\
0\end{array}$ \\
\hline
\end{tabular}

TABLE 5

CASES WITH VISUAL SYMPTOMS, NEPHROPATHY OR HYPERTENSION

\begin{tabular}{|c|c|c|c|c|c|}
\hline Sex & Retinitis & $\begin{array}{c}\text { Albuminuria } \\
\text { (mg. \%) }\end{array}$ & $\begin{array}{l}\text { Blood Pressure } \\
(\mathrm{mm} . \text { Hg) }\end{array}$ & Duration (years) & Control \\
\hline $\begin{array}{l}\mathbf{F} \\
\mathbf{M} \\
\mathbf{M} \\
\mathbf{F} \\
\mathbf{M} \\
\mathbf{M} \\
\mathbf{M} \\
\mathbf{M} \\
\mathbf{M}\end{array}$ & $\begin{array}{l}\text { IV } \\
\text { IV } \\
\text { IV } \\
\text { III } \\
\text { III } \\
\text { II } \\
\text { II } \\
\text { II } \\
\text { II }\end{array}$ & $\begin{array}{r}70 \\
200 \\
300 \\
95 \\
-400 \\
80 \\
550 \\
70\end{array}$ & $\begin{array}{c}175: 98 \\
= \\
\bar{z} \\
160: 110 \\
150: 96 \\
=\end{array}$ & $\begin{array}{l}24 \\
25 \\
22 \\
15 \\
25 \\
22 \\
24 \\
26 \\
19\end{array}$ & $\begin{array}{l}\text { A } \\
\text { A } \\
\text { C } \\
\text { C } \\
\text { B } \\
\text { B } \\
\text { B } \\
\text { A } \\
\text { C }\end{array}$ \\
\hline
\end{tabular}

the sounds altered as the diastolic pressure. In Table 5 the cases with visual symptoms, nephropathy and hypertension are summarized. It will be noted that

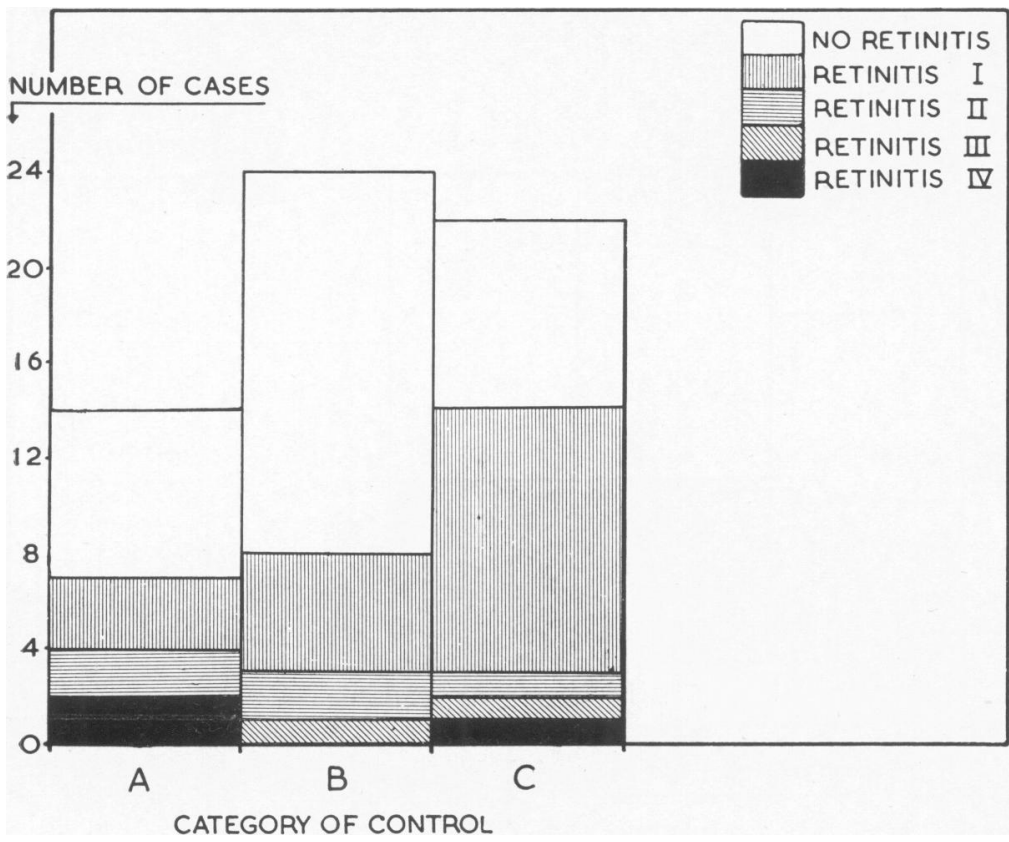

FIG. 5.-Relation of retinitis to control in 60 cases having had diabetes for nine years or more. albuminuria was present in all the blind and all the hypertensive patients. Of the nine patients, three fall into each of the categories A, B and C.

In contrast, the eight patients free of complications after 20 years of diabetes are listed in Table 6. The two with diabetes of over 25 years' duration were among those seen by $\mathrm{Mr}$. Doggart. The woman had negative radiographs of the limb vessels and the young man is a successful long-distance racing cyclist. In this group of patients who have done well, there are two each of the $A$ and $C$ categories and four in the B category.

\section{Discussion}

Now that it is generally accepted that diets of full calorie value are essential for the normal growth and development of diabetic children, the only argument in favour of weighed diets is that by strictly controlling the food intake blood and urine sugars 
TABLE 6

GROUP FREE FROM VASCULAR COMPLICATIONS AFTER 20 YEARS OR MORE

\begin{tabular}{c|c|c|c|c}
\hline Sex & $\begin{array}{c}\text { Age } \\
\text { (years) }\end{array}$ & $\begin{array}{c}\text { Duration } \\
\text { (years) }\end{array}$ & $\begin{array}{c}\text { Insulin } \\
\text { (units) }\end{array}$ & Control \\
\hline F & 29 & 21 & 64 & C \\
M & 28 & 21 & 104 & A \\
F & 30 & 22 & 56 & C \\
M & 24 & 22 & 80 & B \\
M & 27 & 22 & 104 & B \\
M & 31 & 23 & 64 & B \\
F & 34 & 25 & 56 & B \\
M & 30 & 26 & 88 & A \\
\hline
\end{tabular}

may be kept nearly normal. However, it is a mistaken assumption that a young diabetic is well balanced merely because he is keeping to his diet. Many other factors are involved in the regulation of blood sugar, such as the rate of absorption of the food taken and of the insulin from the injection site and the metabolic effects of exercise, environmental stresses or emotional upsets. The lives of young children are so variable that too fine an adjustment of diet and insulin leads to hypoglycaemic attacks which are psychologically detrimental and may even lead to permanent brain damage. Because of these practical problems, it is evident to those with experience in their treatment that absolute control by a strict diet is impossible in the vast majority of children.

The strongest argument against a weighed diet is the difficulty in persuading the patient to keep to it. This reluctance is by no means confined to young diabetics, and was particularly emphasized by Tunbridge (1953) in his lecture on the sociomedical aspects of diabetes mellitus. In a random sample of 103 diabetics attending the clinic at Leeds, only 16 were keeping to the diets, 44 were adhering partially to them and the remaining 43 were either uncooperative in the survey or their dietary habits were described as hopeless. Wilson (1951a), writing from Joslin's clinic about nephropathy in poorly controlled young diabetics, quotes a typical case as follows:

\begin{abstract}
- The child and his parents are carefully instructed concerning the management of the newly discerned disease. Strict compliance with the instructions given about diet and insulin is maintained by the child's parents during the first few months. Gradually carelessness born of familiarity and monotony begins to creep into the management of the child's condition and as the years pass, gross neglect ensues, particularly beyond the age of 15 or 16 when the child has less parental supervision.'
\end{abstract}

These two illustrations are concerned with dietary excesses but in young children the opposite difficulty may also arise, namely refusal to eat, when there is an anxious insistence on the completion of a weighed meal. When such negativism is encountered it is often essential to allow freedom of choice if the child is to get an adequate calorie intake.

What are the results when a free diet is permitted? The standard of control set at the Great Ormond Street clinic has been achieved for more than half of their total diabetic life by 69 of 100 patients. This level of control has been clinically satisfactory on a short-term basis, as the incidence of hypoglycaemic and diabetic coma has been low, the children have been full of energy and have grown well and there has been no neuropathy and no greater an incidence of tuberculosis than would be expected.

In the Annual Report of the Ministry of Health for 1950, the notifications of respiratory tuberculosis between the ages of 15 and 24 years for the general population averaged $0.199 \%$, that is $0.2 \%$ approximately. The incidence in groups of university students in Great Britain and Ireland according to Verney (1955) varied between $0.15 \%$ and $0.34 \%$. Joslin (1952) quoted the incidence of tuberculosis as 12 times higher in diabetics than that of the general population and 20 times higher in adolescent diabetics. Boucot, Dillon, Cooper, Meier and Richardson (1952) reported the results of a survey of tuberculosis in the diabetics of Philadelphia; they used as controls a series of industrial workers balanced for age, sex and colour. The incidence of tuberculosis in diabetics was twice that of the control group, but considering only those aged between 15 and 24 years the incidence $(6 \%)$ was between seven and eight times that of the corresponding controls. The incidence of tuberculosis in our group (4\%) would appear therefore to agree with that in diabetics generally, and although the numbers are small it is notably lower than that quoted by Dunlop (1954) for the free diet clinic in Edinburgh (nine cases out of 50), this being his chief argument against free diets.

The long-term results are compared with those from other clinics for diabetic children in Table 7. The majority of these employed strict diets. Unfortunately, there are no British figures available for comparison. The number of children reported from clinics overseas is small, like our own, except in the case of White's large series. Nevertheless, it is evident that our incidence of retinitis, nephropathy and hypertension is no higher than in any of these clinics, and in some instances it is substantially lower. White's results are worse than those of the smaller clinics possibly because the patients were seen less frequently. Thus the use of practically free diets and the setting of a standard of control that has been attainable most of the time by the majority 
TABLE 7

INCIDENCE OF COMPLICATIONS

\begin{tabular}{|c|c|c|c|c|c|c|c|c|c|}
\hline & & $\begin{array}{c}\text { Duration } \\
\text { (years) }\end{array}$ & $\begin{array}{l}\text { Payne* } \\
\text { (1955) }\end{array}$ & $\begin{array}{c}\text { Larsson* } \\
(1952)\end{array}$ & $\begin{array}{l}\text { White } \\
\text { (1952) }\end{array}$ & $\begin{array}{c}\text { Jackson } \\
(1950)\end{array}$ & $\begin{array}{l}\text { Chute } \\
\text { (1948) }\end{array}$ & $\begin{array}{l}\text { Daeschner } \\
\text { (1951) }\end{array}$ & $\begin{array}{c}\text { Lundbaek } \\
(1953)\end{array}$ \\
\hline \multicolumn{2}{|c|}{ Number of Cases } & $\begin{array}{l}15+ \\
15-19 \\
20+\end{array}$ & $\begin{array}{l}41 \\
19 \\
22\end{array}$ & $\begin{array}{l}33 \\
-\end{array}$ & $\stackrel{?}{702}$ & $\begin{array}{l}34 \\
24 \\
10\end{array}$ & $\begin{array}{l}27 \\
14 \\
13\end{array}$ & $\begin{array}{l}25 \\
10 \\
15\end{array}$ & $\begin{array}{r}24 \\
15 \\
9\end{array}$ \\
\hline Retinopathy & $\cdots$ & $\begin{array}{l}15+ \\
15-19 \\
20+\end{array}$ & $\begin{array}{l}59 \% \\
53 \% \\
64 \%\end{array}$ & $\begin{array}{l}73 \% \\
-\end{array}$ & $\begin{array}{r}50+\% \\
94 \%\end{array}$ & $\begin{array}{l}68 \% \\
58 \% \\
90 \%\end{array}$ & $\begin{array}{l}59 \% \\
42 \% \\
76 \%\end{array}$ & $\begin{array}{l}80 \% \\
70 \% \\
93 \%\end{array}$ & $\begin{array}{r}83 \% \\
71 \% \\
100 \%\end{array}$ \\
\hline Nephropathy & $\cdots$ & $\begin{array}{l}15+ \\
15-19 \\
20+\end{array}$ & $\begin{array}{l}20 \% \\
11 \% \\
27 \%\end{array}$ & $\begin{array}{l}30 \% \\
-\end{array}$ & $\begin{array}{l}-25 \% \\
57 \%\end{array}$ & $\begin{array}{l}6 \% \\
8 \% \\
0 \%\end{array}$ & $\begin{array}{l}29 \% \\
21 \% \\
38 \%\end{array}$ & $\begin{array}{l}32 \% \\
20 \% \\
46 \%\end{array}$ & $\begin{array}{l}25 \% \\
27 \% \\
22 \%\end{array}$ \\
\hline Hypertension & $\cdots$ & $\begin{array}{l}15+ \\
15-19 \\
20+\end{array}$ & $\begin{array}{r}7 \% \\
0 \% \\
14 \%\end{array}$ & $\begin{array}{l}34 \% \\
-\end{array}$ & $\begin{array}{l}-25 \% \\
50 \%\end{array}$ & $\begin{array}{r}6 \% \\
4 \% \\
10 \%\end{array}$ & $\begin{array}{r}19 \% \\
7 \% \\
31 \%\end{array}$ & $\begin{array}{l}36 \% \\
20 \% \\
50 \%\end{array}$ & $\begin{array}{l}33 \% \\
27 \% \\
44 \%\end{array}$ \\
\hline
\end{tabular}

* On free diets.

of the children has not led to any comparative increase either in short-term or long-term complications.

What evidence has been put forward recently in favour of weighed diets? The largest series of young diabetics is that of Wilson et al. (1951a, 1951b, 1951c). The broad outlines of the division of his group into four categories of control is shown in Table 8 and the incidence of retinitis in those diabetic for more than 20 years in Table 9. It will be noted that although a weighed diet was prescribed, only $3 \%$ of the patients were on strictly weighed diets and that $85 \%$ were actually on free diets. This is a further illustration of the reluctance to adhere to strict diets. The group of poorly controlled patients is large and the incidence of retinitis in it is significantly higher statistically than in the other three groups taken together. None of this group exercised any commonsense caution about dieting and some were even irregular in their use of insulin. However, if the fairly well controlled group, who made some effort at controlling of their diabetes, is compared with the good and excellent cases taken together, the difference is very much less marked, and indeed, is not statistically significant. In Dunlop's survey of adults (1954), some details of which are given in Table 10, the poorly controlled group showed the

TABLE 9

WILSON'S RESULTS IN 103 YOUNG DIABETICS (DURATION 20 YEARS +)

\begin{tabular}{|c|c|c|c|c|c|}
\hline \multicolumn{3}{|c|}{ Control } & Number & Retinitis & Percentage \\
\hline Excellent & $\cdots$ & $\cdots$ & 4 & 1 & 25 \\
\hline Good & $\cdots$ & $\cdots$ & 19 & 9 & 47 \\
\hline Fair & $\cdots$ & $\cdots$ & 22 & 13 & 59 \\
\hline Poor & $\cdots$ & $\ldots$ & 58 & 46 & 79 \\
\hline
\end{tabular}

TABLE 10

DUNLOP'S RESULTS IN 167 DIABETIC ADULTS (DURATION 15 YEARS +)

\begin{tabular}{|c|c|c|c|c|}
\hline Control & Number & Percentage & Retinitis & $\begin{array}{c}\text { Percentage } \\
\text { with } \\
\text { Retinitis }\end{array}$ \\
\hline Good & 39 & 23 & 17 & 44 \\
\hline Fair & 53 & 32 & 25 & 47 \\
\hline Poor & 75 & 45 & 59 & 79 \\
\hline
\end{tabular}

TABLe 8

WILSON'S RESULTS IN 247 YOUNG DIABETICS (DURATION 10 YEARS +)

\begin{tabular}{|c|c|c|c|c|c|}
\hline & & & Number & Percentage & Assessment of Control \\
\hline Excellent & $\cdots$ & $\cdots$ & 7 & $3 \%$ & $\begin{array}{l}\text { Weighed diets. } \\
\text { Urine tests more than once every day sugar free before meals. } \\
\text { Clinic visit at least once a year. }\end{array}$ \\
\hline Good & $\cdots$ & $\cdots$ & 30 & $12 \%$ & $\begin{array}{l}\text { Measured diets. } \\
\text { Urine tests once daily sugar free before meals. } \\
\text { Clinic visit at least once a year. }\end{array}$ \\
\hline Fair & $\cdots$ & . & 51 & $21 \%$ & $\begin{array}{l}\text { Urine tests once or twice a week sugar free before meals. } \\
\text { Clinic visit at least every two years. }\end{array}$ \\
\hline Poor & . & $\ldots$ & 159 & $64 \%$ & $\begin{array}{l}\text { Completely free diets. } \\
\text { No routine urine tests. } \\
\text { No routine clinic visits. }\end{array}$ \\
\hline
\end{tabular}


highest incidence of retinitis. The difference in the other two groups was insignificant. While our division of cases into A, B and C groups was not based upon exactly the same criteria as those of Wilson or Dunlop, it was nevertheless evident that again the $\mathrm{C}$ group, that is, those with poor control, showed a higher incidence of retinitis and that the $A$ and $B$ groups were virtually identical in this respect.

Examining why 31 patients should have fallen short of our standard of control for more than half of their diabetic lives, it became clear that, apart from a very few defaulters who would be classified with Wilson's poorly controlled group, the majority were poorly controlled because of a 'brittle' type of diabetes. A period of rigid dieting in hospital failed to improve the control when this was tried in some of the cases. Indeed, it appeared that the success or failure of control depended in many cases on variations in the disease itself rather than on adherence to dietetic instructions whether rigid or simple, as, in contrast to those brittle diabetics, there were the fortunate few who remained consistently in good control, yet who, except for their daily insulin, appeared to ignore their disease entirely.

The first aim of treatment should be to prevent as many children as possible from falling into the category of poor control, as this group undoubtedly shows a higher incidence of retinitis. Too rigorous a method, however, is likely to defeat its own object by provoking rebellion in the child and loss of confidence by the parents. Indeed, more may be gained than lost by using, instead of a strict regime, a simple diet of plain fare and a degree of control which the majority can reasonably hope to attain. A liberal method has resulted in excellent cooperation in the clinic at Great Ormond Street and we believe that successful treatment depends more upon faithful attendance for advice about insulin dosage and the tackling of day-to-day problems than upon the nature of the dietetic treatment advocated.

\section{Summary}

This survey of 100 diabetic children allowed 'free diets' deals with the short-term aspects and also with the incidence of degenerative complications in those who have reached adult life.

As the overall results of treatment have been as good as those obtained by clinics employing weighed diets and because of the psychological advantages and the better cooperation achieved, we believe that the use of a liberal diet will permit the best control in the greatest number of children.

We wish to thank Mr. J. H. Doggart for his assistance with the retina examinations.

\section{REFERENCES}

Allen, F. M. (1914). J. Amer. med. Ass., 63, 939.

(1917). Amer. J. med. Sci., 153, 313.

Boucot, K. R. Dillon, E. S., Cooper, D. A., Meier, P and Richardson, R (1952) 65 Suppl 1 (Jan Pr 2)

Chute, A. L. (1948). Amer. J. Dis. Child., 75, 1.

Daeschner, C. W., Deisher, R. W. and Hartmann, A. F. (1951). J. Pediat., 38, 8.

Dunlop, D. M. (1954). Brit. med. J., 2. 383.

Forsyth, C. C., Kinnear, T. W. G. and Dunlop, D. M. (1951). Ibid. 1. 1095 .

Guest, G. M. (1947). J. Amer diet. Ass., 23, 299.

(1950). In Progress in Clinical Endocrinology, p. 286, ed. S Soskin, New York.

Jackson, R. L., Hardin, R. C., Walker, G. L., Hendricks, A. B. and Kelly, H. G. (1950). Pediatrics, 5. 959.

Joslin, E. P. (1952). In The Treatment of Diabetes Mellitus, Joslin, E. P., Root, H. F., White, P. and Marble, A., 9th ed. London. Larsson, Y., Lichtenstein, A. and Ploman, K. G. (1952). Diabetes, I. 449.

Lichtenstein, A. (1938). J. Pediat., 12183.

(1945). Acta Paediat. (Uppsala), 32. 556.

(1949). Archives of Disease in Childhood, 24. 237.

Lundbaek, K. (1953). Long-term Diabetes. Copenhagen.

Payne, W. W. (1939). Med. Press, 202. 250.

Stolte, K. (1931). Med. Klin., 27. 831

Tunbridge, R. E. (1953). Lancet, 2893.

White, P. (1952). In The Treatment of Diabetes Mellitus, Joslin. E. P et al., 9th ed. London.

Wilson. J. L., Root, H. F. and Marble, A. (1951a). New Engl. J. Med., 245, 513

(1951b). Amer. J. med. Sci., 221, 479.

(1951c). J. Amer. med. Ass., 147, 1526. 